\title{
EUROPE AND THE UNITED STATES IN THE WEST INDIES
}

\author{
By Talcott Williams, LL. D., \\ Philadelphia.
}

The first steps taken by the United States with reference to the determination and collection of the debts of the Dominican Republic have had two opposite effects in the financial circles of Europe. An entire round of bonds, issued at one time or another by governments fronting on the Caribbean Sea and the Gulf of Mexico has abruptly advanced, doubling, trebling and quadrupling in quoted value. At the same time the Belgian bondholders, representing half the face value of the obligations alleged to constitute a lawful claim against the treasury of Santo Domingo, abruptly protest, it is reported, against a proposed arrangement which looks to scrutinizing the validity and equities of the constituent portions of the Dominican debt, meanwhile placing all the revenue available for the payment of interest and amortization in escrow until the work of determining the just debt of the republic, as ascertained by a legal inquiry, is completed.

These opposing views illustrate the opposing principles upon which European powers and the United States take up the problems presented by the population of some $30,000,000$, occupying $2,000,000$ square miles of territory, under I 8 flags, I4 independent and 4 colonial, encircling the waters of the Gulf and the Caribbean. This population, whose total is larger than most appreciate, equalling to-day the population of the United States in 1860 , whose joint territory is twice as large as that country east of the Mississippi, presents essentially one homogeneous problem. Some phases of this problem appear in our own Gulf territory, two of which-Louisiana and Florida-have tracts with a territory and population which, if they were detached and anchored as an island in the gulf, would be as other lands and islands in our tropical Mediterranean. But this 
share of the Gulf coast is removed from current consideration by its national relations. The remainder, nearly one-half the population of Spanish America, is all tropical, all either Indian, negro or hybrid, with not over five per cent. of its population of a pure European origin. Its integers range from Mexico, to-day one of the three most stable of Spanish-American realms, to Santo Domingo, so far as its revenues are concerned in the hands of a receiver, pendente litem. Mexico and Cuba, farthest north, are free from internal instability and enjoy international credit. Even they have their problems. The rest, whether colonies or countries, are steadily gravitating towards bankruptcy. Porto Rico itself could not support the institutions and education of a society civilized or under the process of civilization without disguised aid from the United States. With the two exceptions noted and one other, every independent country in this area has either repudiated its debt or finds it in whole or in part under dispute. Not one but is in a conditon to invite interference. Not one of the fourteen European colonial possessions in this area has a balance sheet which will bear analysis. Even Jamaica, a century ago the wealthiest of all British possessions, for sixty years furnishing the wealthiest British subject, faces yearly deficits or prevents them by a pitiless taxation. It is true of this entire area and all this population that international tutelage in some shape is inevitable. We deceive ourselves if we do not see that the economic bankruptcy of the tropics, which, in a belt running around the world, furnishes examples of decreasing prosperity as visible in Ceylon and Java as in Jamaica and Hayti, in the Congo and Orinoco alike, have brought this particular physiographic basin, lying south of us, about the Gulf and the Caribbean, displaying singularly uniform conditions, to a pass where its supervision by some stronger power is inevitable for its own security and development.

Europe would interfere if the United States did not. Fortunately, as if to furnish an experimental trial and informal plea for the application of our methods and the extension of our theories of administration, the European colonial system has been tried in this area and failed. In Cuba, the Spanish system met economic failure before it faced political collapse. The reconcentrado system had been tried on the agriculture and industries of Cuba before it was tried on its population. In both it was a frank confession of administrative suicide. Jamaica is in its way as complete a failure. 
Growing poorer year by year, its sugar and coffee industries disappearing, its white population diminishing and its taxation increasing without meeting its expenditure, a long series of despairing official reports furnish their own best proof that even British colonial administration above praise in its order, honesty and efficiency, cannot bring prosperity and internal development to an island relatively and absolutely richer and more prosperous a century ago than to-day.

In succession, following the plan of events rather than any systematic national policy, the United States has set itself to the task of the administrative and economic rehabilitation of this region. Our railroad capital and railroad management have played a part in Mexico whose full importance will only become clear when President Diaz closes his long career. The extension of our own railroad system over Mexico has been a powerful factor in maintaining Mexican stability. Should that factor be disturbed in the future, American capital and American interests in Mexico are such as to render it certain that they will constitute an influence as important in restoring stability by the United States through whatever steps the situation may render wise, necessary or inevitable. Fortunately there has been no moment for twenty-five years, and there promises to be none in the future, when the economic development of Mexico will not preserve its political equipoise. Mexico has worked out its own salvation thus far aided by American capital, which has never in a quarter of a century had reason to appeal to its own government even for remonstrance. As much cannot be said for any of the dependent railroad systems planted by external capital in the Iberian or the Balkan peninsula. Mexico, by its internal condition, for years invited interference. It was attempted by European countries, culminating in the ill-starred and disastrous imperial experiment launched by Napoleon III and ended by the United States. Our rigorous abstinence from interference since contrasted with European policy, abortive though it proved, is the best possible proof that one prime contrast between European and American policy in the broad area once mapped as "Los Indos" is that the United States will never interfere or act while there is a hope of local self-rule and internal amelioration.

Where this hope disappears, as unconsciously as we have abstained in Mexico, we act. Already, in a decade at whose opening no man dreamed of its fruits, in the ten years since insurrection 
broke out in Cuba, we have set in order Cuba, annexed Porto Rico, begun our work on the mainland by organizing the "Republic of Panama" and placed Santo Domingo substantially in the hands of a receiver. Already these steps are seen to follow a logical order. The two islands east and west of Hayti have already received our attention. The control of Panama means, when the canal is dug, dominance over the entire basin. The economic annexation of Jamaica is in rapid progress by the extension of fruit industries on the island through our demand and our capital and by the demand for Jamaican labor on the canal. This demand under the French company has begun the work of transforming Jamaica into an island of small landholders, and by the time the canal is dug this transformation will be complete, the industry which we are stimulating on the island by our consumption of bananas being (unlike sugar and coffee fostered by English policy and English taxes) directly favorable to the small landholder. Many signs show that he is increasing in Cuba and Porto Rico. Where Spanish and English taxation aids the large landholder, our sytems of taxation aid the small as fast and as far as they are introduced. The Jamaica negro goes to Panama to save the money to buy a small holding on his return. It is safe to predict that Cubans and Porto Ricans will show a like land appetite. The small landholder never appeared on any great and growing scale in Jamaica until the Panama canal began to be dug. By the time we have spent $\$ 175,000,000$ on the canal, most of it for labor, we shall have rendered possible the purchase of small plots of tropical land on an enormous scale in the Greater Antilles. Exactly as our taxation, where it is introduced, as in Porto Rico, is inimical to the large plantation-a change inevitable in Cuba and in progress in our own Southern and Gulf States (numerically half the landholders in South Carolina are blacks), so our economic advent in large and unprecedented expenditures on the canal is about to give the great laboring population of this tropical area an opportunity it has never had under plantation conditons to buy land. The European colonial systems, institutions and taxes, England's as well as Spain's, work for the plantation, and are drawn, enacted, conducted and collected by those in sympathy with the plantation. Unconsciously, for I am dealing not with statute and treaty, but with deeper forces, which regulate statute and treaty, our appearance in this great maritime basin (bankrupt 
under European policies or their inheritance in tax systems-such as they are-of Spanish-American communities) is about to supplant the long decay for a century of the plantation by the manifold multiplication of the small landholder-already in full progress, as I have said, in Jamaica.

In the political framework we are creating at our entrance on this great task of raising to an efficient industrial civilization a tropical territory two-thirds as large as our own area between the oceans and a population a third of ours, we are as unconsciously following the germs of our institutions. With a political initiative and a political prudence and prescience as worthy in its way and day as that which organized our federal constitution, we are extending its principles and applying them to new needs. The concentric circles of our constitutional system steadily grow and extend. We began a confederation of equal sovereignties. Before we became an indissoluble union of indestructible states we had added to the states within our union, territories without it. These began as communities temporarily waiting for statehood. The Louisiana purchase added territories to wait nearly a century for sovereignty, and part of that acquisition, as early claimed, has passed the centennial of that event without admission as a state. A half century finds part of our Mexican purchase lacking all the requisites for a state, opening a third category of contiguous territory liable to be retained as a territory over more than one generation. Our insular possessions opened a fourth category of territory non-contiguous which no one now living expects to see admitted to statehood and which probably never will be so admitted. With Cuba a fifth category of territory appeared, sovereign-a state in our federal system is that-but also independent and left free, subject to preserving, under the Platt amendment, a certain standard of internal order, civil sanitation and public credit. Between this and an island like Porto Rico appears Santo Domingo, its revenues controlled and paid into court pending the satisfaction of creditors; but its internal affairs left free as long as they remain peaceful and stable, with changes in government and rule proceeding only in accordance to law and not by violence.

It is impossible to avoid seeing here, visible to the apprehending political sense and felt by the historic instinct, a general system and network of public law, written and unwritten, following in one continuous logical course. The states with full national powers, the 
territories waiting admission, territories unlikely of this, islands excluded even from this prospect within our current and immediate political horizon, other islands like Santo Domingo and Cuba, each in its need, degree and capacity left free or restrained in certain particulars, all revolving in an American system wider even than our national union, an American system whose final bonds and bounds are the two continents and the hemispheres covered by the Monroe Doctrine-who can see this and not perceive here the growth of one continuous, coherent, logical political system in which, as in our Union, the old problem of a central rule strong enough for national needs and a local rule preserving all that is needed in each instance for local initiative and development, is being worked out as are all vital political systems, not by enactment, but by growth.

If any man challenge the use of "law" with reference to a public policy like the Monroe Doctrine, one can but answer that this legislation for a hemisphere expresses the overt will of $80,000,000$ out of $160,000,000$ of its population and the assent of all the rest. Of the white and civilized population, $70,000,000$ out of $90,000,000$ have asserted and defended it. Few of the world's laws, written or unwritten, have behind them an enactment more august or, one may add, are backed by a more puissant phyical force.

Viewed in this broad perspective and this wide aspect, our federal union, its states, territories and insular possessions, islands under special relations and the entire area from which European colonization and ambition are excluded, become part of one great growth and development, as indivisible as the hemisphere, in which, as in our Union, no authority and no sovereignty is absorbed by the central power whose possession is not necessary to the peaceful development, the unchallenged security and the freedom under law of each separate and individual part.

If from the area dedicated to this great experiment not only in self-government, but to training in the capacity for future self-government, we exclude by a national instinct now but a little over a decade removed from its centenary, all perturbing European influences, it is because these influences are based upon a different view of centralized sovereignty. Most of all is this true in the islandrimmed seas and rimming coasts we are considering. Even England in Jamaica, ready as she is in granting colonial self-government, has for a century reduced the powers of the local legisla- 
ture of the island. Where in Porto Rico, a closely similar island, we have studied how much we could grant of local control, English policy in the twoscore years since Jamaican charter rights were surrendered has sought to see how much could be withheld. Where we kept our pledge and withdrew from Cuba, England, wisely or unwisely, disregarded its pledges and remained in Egypt. No European administrator would have felt safe in leaving Havana. No American administrator felt safe in remaining there. When Spain forty years ago attacked the problem of Santo Domingo it was by an armed occupation which sought sovereignty. With far greater power at our command we avoid an armed occupation, leave local sovereignty untouched and limit our proposed interference to the one point whose stability and protection, experience shows is necessary to the removal of temptations to a breach of internal order and the consequent subversion of public credit, with its grave invitation to international interference on behalf of repudiated obligations. The one view in which debts present themselves to European public opinion is as offering a reason for their collection. The one view, the same obligations present themselves to American public opinion is as offering a reason for ascertaining their justice.

Our national experience, for over a century of sovereign states schooled in submission and obedience to law, has trained us to regard law as superior even to the acts and policy of nations. We see no reason in Santo Domingo or anywhere else why a claim should be urged at the cannon's mouth unless it can first be justly argued in a court of law or bear a legal investigation. If dubious Spanish-American bonds rise on European exchanges, it is because our position is misunderstood by those who have seen Tunis and Egypt saddled with bonds whose face never stood for any valid payment into the public treasury for public purposes. They expect the same of us in the region under consideration in this meeting and in the arena of events. If it is true Belgian bondholders, as reported, object to our method, it is because they are aware of the grave risks raised for them, if inquiry begins and public equities are considered in public debts.

Doubtless this view, which we are introducing in Santo Domingo, in sharp contrast with the steps taken forty years ago to collect Mexican debts and more recently Venezuelan, runs counter to the European view that each sovereign state must be the judge of 
the means, methods and measure with which it enforces the obligations and claims of its subjects against another state, particularly if the state is weaker. We have learned through a century of constitutional law that "the glories of our blood and State are shadows, not substantial things," unless they rest on the assured foundation of law. It is a narrow view to look upon the work of John Marshall and our supreme court as simply expounding and establishing the principles of our federal constitution and setting in their due relations federal and state powers. Our great judge was the first to accustom man to the conception that sovereignty itself is the creation of law. When he began his work, ultimate sovereignty, whether it was the popular assembly of Poland, the king of France or Parliament in England, was looked upon in the eighteenth century as superior and supreme over law. In a series of great decisions Marshall recalled men to the fundamental conception that sovereignty itself obeyed law, and when to this was added the still greater conception that international law was binding upon the action of the sovereign in international affairs, a doctrine first laid down by our supreme court, another step was taken in the assertion of liberty through law.

This principle was early applied, first unconsciously and then consciously in the Monroe Doctrine. There is no right and power in which sovereignty had been before more free than in the acquisition of territory. None in which sovereignty had been more jealously guarded than in its cession. When, under the Monroe Doctrine, the American continent was closed to the colonial adventures of Europe, a law was enunciated which controlled the appetite of the strong and the temptations of the weak. Step by step these restrictions were widened. They began with the application to colonial schemes. The work passed on to a veto upon the attempt in Mexico to establish a government aided by a foreign power, though in no sense itself a colony. A generation later in the Venezuela arbitration it was settled that no boundary could be adjusted between an American power and a European colony without resorting to this wider law which was asserted to control the negotiations of the most powerful maritime power in the world. In the same broad region where the voice of law has spoken on these issues there is unrolling before us the application of. law to the entire congeries of claims resting on alleged bonds, recklessly repudiated on one side and as 
ruthlessly asserted on the other as demanding and deserving the application of force for their face payment. Instead the United States proposes, following the instincts of a past which submits all to law, that these claims also shall be tried by the rules and equity of law and that neither the debtor shall pay nor the creditor assert claims not capable of a legal adjudication before a competent tribunal. Once establish this and the lack of capital which is halting the growth of all the rich tropical area with the unrivaled water communication of our Mediterranean, gulf and sea and their numerous harbors, disappears, without establishing that slavery to the bondholder which rests a heavy burden on the industries and the agriculture of several of the lands about the European Mediterranean.

To the difficult task imposed by the condition, the population the past history and climate of these lands and islands between the equator and the thirtieth parallel, the United States addresses itself with a confidence born of our own success and the methods tried in our own national development. Nowhere does the contrast between European and American influence in the West Indies appear more clear than when the comparison is made between the best colonial administration known, that in operation under the British flag in Jamaica, and our own policy in Porto Rico. The two islands are of nearly the same size, with nearly equal population, negro and negroid, one English in its admixture of white blood and the other Spanish. They lie side by side, substantially alike in resources, climate, soil and markets. Where British administration provides roads, over which the people who pay for them with their labor walk barefoot, our policy has been to provide schools. Porto Rico after seven years has twice the relative attendance in school of Jamaica sixty-five years after emancipation. The high peace and order of Jamaica is secured by a police force whose command is English. In Porto Rico we have sought to develop a constabulary to be in the end under native command. Pensions to English officeholders are a heavy charge in Jamaica. In Porto Rico the training of teachers is conspictous in the budget. Higher education is unsupported in Jamaica. The island is intellectually dependent. In Porto Rico our educational policy moves towards higher institutions of learning and a university. Jamaica pays for a garrison, Porto Rico has no such charge to meet. Self-government is restricted in 
Jamaica. It is carried to the verge of safety in Porto Rico. The English taxation aids the planter. Ours the small occupier. Their taxes make food dear for the man. Ours cheapen it. Their revenue system taxes occupation. Our taxes are laid on property. Jamaica is treated like an island always to be in leading strings. Porto Rico is under preparation for increasing responsibilities. Immediate prosperity is greater in Jamaica. The future holds more for Porto Rico. Our policy doubtless has the inevitable disturbance of dynamic development. English administration the calm and the arrest of static conditions. 